Landina A. V. Ensuring of criminal liability of a special subject of a crime by the norms of the General part of the Criminal Code of Ukraine

The guarantee of objectivity and justice as the basic principles of criminal law is to take into account all the essential circumstances of a specific crime. The value of identifying the features of a particular object of a crime is that it represents a combination of these attributes and determines whether a person can be prosecuted in general and, depending on this, whether there is a general crime event. From the point of view of the connection of personal or social (quantitative or qualitative) features of the person who committed a crime that affects the qualification of the crime and the choice of the type and size of the sentence by the court, the norms and institutions of the general part of the Criminal Code of Ukraine, criminal liability of the special unit Crime the object was not considered.

The purpose of this article, taking into account the lack of research on the state of ensuring criminal liability of special crime subjects, is the establishment of means of legal monitoring, how in general rules determine the specificity of criminal liability of a particular object. crime, and how these traits are taken into account in bringing a person to criminal responsibility and punishment.

The vast majority of crimes are carried out on special subjects: out of 387 articles of the Special Part of the Criminal Code of Ukraine, those who undoubtedly establish the criminal responsibility of a particular subject of a crime (mostly unskilled), include 235 articles, $60.8 \%$ of the total number of articles in a special section The Criminal Code of Ukraine.

In general, the peculiarities (criteria) that define the subject of a crime as special, affecting the type and size of the sentence that may be imposed, and the possibility of filing a lawsuit against the offender, other general provisions specified in the norms of the General Part of the Criminal Code of Ukraine. These criteria include quantitative characteristics (complicity and repetition, aggregate and relapse) and qualitative (age, occupation, occupation, gender, health status).

Given the foregoing, the overwhelming majority of the norms of the General Part of the Criminal Code of Ukraine ensures the legality, fairness and objectivity of bringing to criminal liability those who, together with the mandatory (as defined in part one of Article 18)). The Criminal Code of Ukraine), endowed with special features arising from their criminal liability.

Given the number and variety of features that determine the subject of a crime as a special, further researches should be aimed at improving criminal legislation in terms of determining the specifics of the special object of the crime.

Key words: criminal liability of a special subject, legal monitoring of the norms of criminal legislation, quantitative characteristics, qualitative characteristics.

DOI: 10.33.66.3/2524-017X-2019-10-325-329

УДК 340

\author{
Микола Олександрович Пухтинський, \\ кандидат юридичних наук, дочент, \\ стариий науковий співробітник відділу \\ конституиійного права та місиевого \\ самоврядування Інституту держави і права \\ ім. В. М. Корецького НАН Украӥни
}

\title{
СУБ'ЄКТИ КОНТРОЛЬНОЇ ДІЯЛЬНОСТІ У МІСЦЕВІЙ ПУБЛІЧНІЙ ВЛАДІ
}

Постановка проблеми. Визначення змісту контрольної діяльності у місцевій публічній владі, місцевому врядуванні Україні потребує дослідження складу ії суб'єктів та їх законодавчого закріплення.

Аналіз останніх досліджень та публікацій. Проблематика контролю, контрольної діяльності у сфері місцевої публічної влади, місцевого врядування стала предметом багатьох наукових доробок: юридичних, політологічних, державно-управлінських. Контролю присвячено чимало академічних монографічних, енциклопедичних, дисертаційних досліджень. У цьому ж контексті акцентуємо також увагу на фундаментальні роботи з теорії держави і права, конституційного, адміністративного, муніципального права, зокрема, на наукові твори В. Б. Авер'янова, О. Ф. Андрійко, О. В. Батанова, В. І. Борденюка, А. Р. Крусян, О. І. Сушинського, сучасні дисертаційні дослідження 
С. С. Вітвіцького, Б. В. Калиновського, Т. О. Карабін, С. А. Косінова, Н. В. Никитченко, Д. А. Опаленко, К. В. Пивоварова, О. В. Савченко, О. Д. Скопича, О. А. Смоляра, В. В. Тароєвої.

Мета статті. Дослідити стан конституційно-правового визначення та законодавчого забезпечення складу суб'єктів контрольної діяльності у місцевій публічній владі.

Основні результати дослідження. При визначенні кола суб'єктів контролю, контрольної діяльності у місцевій публічній владі доцільно розглянути ряд теоретичних положень щодо публічної, муніципальної влади, публічної адміністрації в контексті предмета дослідження, які знайшли відображення в юридичній літературі.

Так, О. В. Батанов дає наступне теоретичне бачення сутності публічної, муніципальної влади: «Як інститут конституційного права та категорія сучасного конституціоналізму за своєю суттю муніципальна влада - це легітимне публічно-самоврядне волевиявлення територіальної громади, що являє собою здійснення народовладдя на локально-територіальному рівні, самостійний вид суспільної політичної влади; за своїм змістом муніципальна влада являє собою здійснення функцій місцевого самоврядування, спрямованих на реалізацію прав та свобод людини і громадянина в межах власних (самоврядних) повноважень та окремих наданих державних повноважень; за формою муніципальна влада - це прийняття і реалізація правових актів у порядку, передбаченому Конституцією і законами України, а також нормативними актами місцевого самоврядування»[1, с. 221].

Варто також звернутись до теоретичних роздумів про публічну владу А. Р. Крусян, яка, зокрема, зазначає: «Влада, що поширюється на всіх членів суспільства, а не на окрему особу, і має таку властивість, як загальність, має суспільний характер, тобто $є$ публічною. Ця влада поширюється за територіальним принципом, їй підкоряються всі, хто перебуває на певній території. Публічна влада здійснюється не тільки державою. Державна і самоврядна влада в сукупності - суть публічна влада... Слід виходити з того, що місцеве самоврядування в Україні - це самостійна, недержавна, місцева публічна (публічно-самоврядна) влада територіальних громад...Таким чином, державна і самоврядна влади $є$ самостійними формами публічної влади - інституціональними складовими сучасного конституціоналізму. При цьому, місцеве самоврядування має спеціальний суб'єкт (територіальну громаду), спеціальний об'єкт (питання місцевого значення), воно має таку властивість, як самостійність - ключова категорія, що характеризує місцеве самоврядування як самостійну підсистему публічної влади (самоврядну)»[2, с. $335,358,360]$.

Б. В. Калиновський, який досліджує конституційно-правові засади місцевої публічної влади в Україні вважає, що «це свідомо-вольове відношення між людьми та їх організаціями, які проживають, перебувають або розташовуються на певній території, у процесі якого ті, що мають владу, здатні шляхом прийняття легітимних рішень вирішувати справи суспільного значення та визначати поведінку підвладних для забезпечення реалізації прав і свобод людини і громадянина, функціонування та розвитку території на конституційно-правових засадах, спираючись у необхідних випадках на можливість примусу. Ознаки: є свідомо-вольовим відношенням між людьми, або їх організаціями; має територіальне підгрунтя; передбачає процес, під час якого ті, що мають владу, визначають поведінку підвладних, спираючись на можливість примусу; ії джерелом є український народ; містить дві складові; реалізується стосовно спеціального об'єкта; має конституційний характер» [3].

O. I. Сушинський пропонує таку дефініцію публічної влади: «це стан векторіального функціонування суспільних відносин, що здійснюється шляхом їх контролю через різні види діяльності: установлення (законодавчої); виконання (виконавчої); забезпечення (судової); відновлення, встановлення, констатування та спрямовування (контрольної) тощо» [4].

О. А. Смоляр вірно зауважує: «Контроль над публічною владою поряд з механізмами її обмеження і стримування виступає важливим складником конституціоналізму... Контроль за органами публічної влади в цілому і органами місцевого самоврядування зокрема $є$ різновидом соціального контролю, який покликаний забезпечувати збереження і розвиток соціальної системи, упорядковане функціонування ії елементів. Соціальний контроль $є$ механізмом підтримки соціальної рівноваги, який забезпечує життєдіяльність сучасного суспільства й ефективність його соціального управління» [5].

С. С. Вітвіцький під поняттям «публічна адміністрація» розуміє систему органів виконавчої влади та органів місцевого самоврядування, які виконують делеговані повноваження виконавчої влади, що, на думку автора, дозволяє об'єднати суб' єкти виконавчої діяльності, врахувати публічний характер такої діяльності, а також управлінський зміст терміна «адміністрація» [6].

Т. О. Карабін визначає зміст категорії «публічна адміністрація», що розкривається в організаційно-структурному аспекті, як сукупність органів та посадових осіб, що реалізують публічну владу 
шляхом виконавчо-розпорядчої діяльності, а також доводить недоцільність включення до суб'єктного складу публічної адміністрації суб'єктів, для яких виконавчо-розпорядча діяльність не є основною та визначальною, оскільки це призведе до збігу та однакового змістового наповнення понять «суб'єкт адміністративного права» та «публічна адміністрація» [7].

На думку А. І. Буханевича: «На сучасному етапі суспільно-політичного та економічного розвитку сучасної політичної системи важлива роль належить розробці перспективних напрямів формування та функціонування публічної адміністрації як одного з інститутів оптимізації форм публічного контролю в громадянському суспільстві. У нашому розумінні публічна адміністрація являє собою таку інституційну структуру організації діяльності органів державної влади та місцевого самоврядування, яка забезпечує демократизацію державного управління шляхом створення широких можливостей для налагодження взаємодії влади та громадськості» [8].

С. А. Косінов дає теоретико-правову характеристику контролю над публічною владою та акцентує на тому, що: «Контроль над публічною владою виступає різновидом соціального контролю; є поєднанням суб'єктно-об'єктних властивостей на різних рівнях управління, що знаходить свій прояв, зокрема, у тому, що: 1) кожен суб'єкт, виконуючи свої функції, одночасно виступає як об'єкт для суб'єктів більш високих рівнів; 2) кожен об' єкт виконує двоїстого роду функції суб'єкта: у найбільшому обсязі у межах конкретної організації в порядку саморегулювання і в певних межах і формах участі в діяльності вищого та інших суб'єктів; 3) наявність змішаних суб'єктів та об'єктів, коли існують об'єкти, що є спільними для багатьох суб'єктів; суб'єктом контролю над публічною владою виступає народ - або безпосередньо, або в особі уповноважених органів, наділених від імені народу відповідними контрольними повноваженнями; контроль над публічною владою об’єднує в собі такі елементи, як державний контроль, громадський і міжнародний» [9].

С. С. Вітвіцький виділяє спільні та особливі риси категорій «суб'єкт контролю» та «суб’єкт контролю діяльності публічної адміністрації». Він вважає, що категорія «суб’єкт контролю» може сприйматись як правова абстракція в разі якщо формується загальне уявлення про контроль та сутність відповідних правовідносин; категорія «суб' єкт контролю діяльності публічної адміністрації» визначається 3 позицій матеріального суб'єкта, який потенційно або реально бере участь у контрольних правовідносинах. В той же час, слід розрізняти категорії «суб’єкт контролю» і «суб'єкт контрольної діяльності», які співвідносяться як ціле і частка. Спільними в цих категоріях, на думку автора, є те, що обидві є правовими категоріями, які не можуть існувати поза межами правовідносин контролю. Різниця полягає в тому, що категорія «суб’єкт контролю» є загальною і означає потенційну можливість певного матеріального об'єкта брати участь у правовідносинах контролю. Така потенційна можливість визначається насамперед встановленням у чинному законодавстві та закріпленням правовою нормою (як правило, нормою адміністративного права) компетенції щодо здійснення контролю. На відміну від загальної категорії «суб'єкт контролю», категорія «суб'єкт контрольної діяльності» має конкретне значення як учасник правовідносин щодо здійснення контролю діяльності публічної адміністрації [10].

Представлені міркування дають змогу зробити деякі попередні висновки щодо аксіології контролю, контрольної діяльності у місцевій публічній владі з огляду на вимір місцевого врядування. Більшість дослідників розглядають контроль та контрольну діяльність 3 позиції широкої концепції його соціальної природи і призначення. В той же час, категорії «публічна влада», «публічна адміністрація» обмежують склад суб'єктів контрольної діяльності та контролю державно-владними і муніципально-владними інститутами. Переважно йдеться про місцеві органи виконавчої влади та органи місцевого самоврядування. Деякі автори навіть вважають, що до суб'єктів державного, адміністративного контролю можна віднести лише тих, хто безпосередньо виконують виконавчо-розпорядчі функції і повноваження (цитоване дослідження Т. О. Карабін).

Вбачаємо, що контроль, контрольна діяльність, суб’єкти контролю у місцевій публічній владі з точки зору виміру місцевого врядування дозволяє окреслити склад цих суб'єктів.

До суб'єктів контрольної діяльності в системі місцевих органі виконавчої влади відносяться місцеві органи виконавчої влади загальної компетенції, місцеві органи виконавчої влади спеціальної компетенції, а також місцеві органи виконавчої влади, правовий статус, повноваження яких пов'язані із здійсненням суто контрольної діяльності. До зазначених органів загальної компетенції відносяться районні, обласні, Київська, Севастопольська та районні в цих містах державні адміністрації. До органів спеціальної компетенції входять територіальні органи центральних 
органів виконавчої влади, які здійснюють виконавчо-розпорядчу діяльність, управління різними сферами життя населення на певній території та визначені у законодавстві контрольні функції. До органів із суто контрольними повноваженнями відносяться спеціалізовані місцеві органи виконавчої влади у певних сферах фінансового, екологічного, санітарного, архітектурно-будівельного, тощо контролю.

У системі місцевого самоврядування такими суб'єктами є: територіальна громада, представницькі і виконавчі органи місцевого самоврядування, відповідні сільські, селищні, міські голови, голови районних, обласних, районних у містах рад, голови об'єднаних громад, органи самоорганізації населення, старости, депутати місцевих рад, постійні комісії місцевих рад, секретар сільської, селищної, міської ради, відділи, управління та інші виконавчі органи сільської, селищної, міської, районної у місті ради.

Суб’єктами контролю і контрольної діяльності у місцевій публічній владі, місцевому врядуванні є також інститути громадянського суспільства, які займають самостійне місце в механізмі контрольної діяльності, зокрема щодо проведення громадської експертизи діяльності органів виконавчої влади. При цьому в Постанові Кабінету Міністрів України про порядок проведення такої експертизи зазначено: «Громадська експертиза діяльності органів виконавчої влади (далі - громадська експертиза) $є$ складовою механізму демократичного управління державою, який передбачає проведення інститутами громадянського суспільства, громадськими радами оцінки діяльності органів виконавчої влади, ефективності прийняття і виконання такими органами рішень, підготовку пропозицій щодо розв’ язання суспільно значущих проблем для їх врахування органами виконавчої влади у своїй роботі.

У цьому Порядку під інститутами громадянського суспільства слід розуміти громадські об'єднання, професійні спілки та їх об’єднання, творчі спілки, організації роботодавців та їх об'єднання, благодійні і релігійні організації, органи самоорганізації населення, недержавні засоби масової інформації та інші непідприємницькі товариства і установи, легалізовані відповідно до законодавства» [11].

Опосередковано суб’єктами контролю у місцевому врядуванні є вищі та центральні органи публічної влади, які видають акти, приймають рішення щодо контрольної діяльності інституцій місцевого врядування. До таких органів відносяться Верховна Рада України, Президент України, Кабінет Міністрів України, центральні органи виконавчої влади, Конституційний Суд України, Рахункова палата України, Уповноважений Верховної Ради України з прав людини.

Склад суб'єктів контрольної діяльності у місцевій публічній владі, їх правовий статус, компетенція щодо здійснення контролю, реалізації контрольних повноважень обумовлені сучасною системою місцевих органів виконавчої влади, системою місцевого самоврядування, що визначені у Конституції та законодавстві України.

Конституція України окреслює контури складу суб’єктів контролю у місцевому врядуванні, місцевій публічній владі. Це, зокрема, норми, що визначають конституційні засади системи виконавчої влади та місцевого самоврядування. Серед них положення розділу VI Конституції України «Кабінет Міністрів. Інші органи виконавчої влади». Так, в статті 116 Конституції закладаються конституційні основи функцій і компетенції Кабінету Міністрів України. Стаття 118 Конституції визначає коло суб' єктів місцевих органів виконавчої влади в особі місцевих державних адміністрацій: «Виконавчу владу в областях і районах, містах Києві та Севастополі здійснюють місцеві державні адміністрації. Особливості здійснення виконавчої влади у містах Києві та Севастополі визначаються окремими законами України». На систему територіальних органів виконавчої влади та місцевого самоврядування безпосередньо впливають конституційні приписи IX розділу Конституції «Територіальний устрій України». В розділі Х Конституції визначаються засади державних інституцій Автономної Республіки Крим. Нарешті, положення ХІ розділу Конституції у статтях 140, 141 закладають основи щодо діяльності суб’ єктів системи місцевого самоврядування [12].

Деталізація складу суб'єктів контролю у місцевому врядуванні, місцевій публічній владі міститься у відповідних положеннях законодавства, присвяченого органам виконавчої влади та місцевому самоврядуванню.

Тут насамперед слід позначити: Закони України: Про Кабінет Міністрів України, Про центральні органи виконавчої влади, Про місцеві державні адміністрації, Про військово-цивільні адміністрації, Про місцеве самоврядування в Україні, Про органи самоорганізації населення, Про статус депутатів місцевих рад; Указ Президента України «Про оптимізацію системи центральних органів 
виконавчої влади»; постанову Кабінету Міністрів України «Про оптимізацію системи центральних органів виконавчої влади» [13].

E також окремі законодавчі акти, в яких дається власне визначення контролю та складу його суб'єкті відносно сфери законодавчого регулювання. В Законі України «Про основні засади державного нагляду (контролю) у сфері господарської діяльності» дається визначення «державного нагляду (контролю)» та окреслюється коло суб'єктів у цій сфері. Згідно з Законом «державний нагляд (контроль) - діяльність уповноважених законом центральних органів виконавчої влади, їх територіальних органів, державних колегіальних органів, органів виконавчої влади Автономної Республіки Крим, місцевих державних адміністрацій, органів місцевого самоврядування (далі органи державного нагляду (контролю) в межах повноважень, передбачених законом, щодо виявлення та запобігання порушенням вимог законодавства субъєктами господарювання та забезпечення інтересів суспільства, зокрема належної якості продукції, робіт та послуг, допустимого рівня небезпеки для населення, навколишнього природного середовища» [14].

К. В. Пивоваров виділяє наступні специфічні ознаки державного контролю у сфері виконавчої влади: «в переважній більшості випадків між органом, що здійснює повноваження контролю, та підконтрольними об' єктами існують характерні адміністративні відносини підлеглості чи підвідомчості; об’єктом контролю у сфері виконавчої влади, як правило, є не лише питання дотримання закону, а й ефективність діяльності контрольованих об'єктів; доволі часто суб'єктам правового контролю надається право відміняти рішення, що були прийняти підконтрольними їм органами; органи контролю у багатьох випадках наділяються правом приймати рішення щодо застосування різноманітних мір впливу щодо контрольованих ними органів за припущені ними правопорушення» [15].

Серед місцевих органів виконавчої влади, як суб'єктів контрольної діяльності, слід виділити територіальні органи центральних органів виконавчої влади та відповідні місцеві державні адміністрації. Важливу роль в забезпеченні контролю, здійсненні контрольної діяльності відіграють місцеві державні адміністрації. Відповідно до Закону «Про місцеві державні адміністрації» (ст. 1): «Виконавчу владу в областях і районах, містах Києві та Севастополі здійснюють місцеві державні адміністрації».

Склад суб'єктів контрольної діяльності в системі виконавчої влади в законодавстві чітко не визначений. Хоча його можна 3'ясувати при аналізі положень законодавчих актів, спрямованих на оптимізацію системи центральних органів виконавчої влади. До них відносяться чинний Указ Президента України «Про оптимізацію системи центральних органів виконавчої влади» від 9 грудня 2010 р. [16] та постанова Кабінету Міністрів України «Про оптимізацію системи центральних органів виконавчої влади» від 10 вересня 2014 р. [17].

В Указі та постанові реформовано систему центральних органів виконавчої влади, які, зокрема, здійснюють контрольні повноваження. Так, в Указі визначено: утворення відповідних міністерств, державних служб, державних агентств та інспекцій, ліквідовано та реорганізовано цілий ряд центральних органів виконавчої влади, а також затверджено Схему організації та взаємодії центральних органів виконавчої влади, в якій виділено: міністерства, центральні органи виконавчої влади, центральні органи виконавчої влади зі спеціальним статусом, центральні органи виконавчої влади, діяльність яких спрямовується і координується Кабінетом Міністрів України через відповідних членів Кабінету Міністрів України.

У згаданій Постанові осучаснено систему державних служб, агентств, інспекцій і також затверджено схему спрямування і координації діяльності центральних органів виконавчої влади Кабінетом Міністрів України через відповідних членів Кабінету Міністрів України. Приміром, в плані здійснення контрольних повноважень утворено: Державну службу України з питань безпечності харчових продуктів та захисту споживачів, реорганізувавши шляхом перетворення Державну ветеринарну та фітосанітарну службу і приєднавши до Служби, що утворюється, Державну інспекцію з питань захисту прав споживачів і Державну санітарно-епідеміологічну службу та поклавши на Службу, що утворюється, функції з реалізації державної політики, які виконували органи, що припиняються (крім функцій з реалізації державної політики у сфері племінної справи у тваринництві, у сфері охорони прав на сорти рослин, у сфері епідеміологічного нагляду (спостереження), у сфері гігієни праці та функцій із здійснення дозиметричного контролю робочих місць і доз опромінення працівників), а також функції із здійснення державного контролю (нагляду) за дотриманням вимог щодо формування, встановлення та застосування державних регульованих цін; здійснення державного нагляду (контролю) у сфері туризму та курортів тощо. 
Законодавство визначає коло суб’єктів контрольної діяльності у місцевому самоврядуванні. Насамперед - це положення Закону України «Про місцеве самоврядування в Україні».

У першій статті Закону «Основні терміни, використані в цьому Законі» окреслюється склад основних суб'єктів. В статті 5 Закону визначається система місцевого самоврядування, яка включає: територіальну громаду; сільську, селищну, міську раду; сільського, селищного, міського голову; виконавчі органи сільської, селищної, міської ради; старосту; районні та обласні ради, що представляють спільні інтереси територіальних громад сіл, селищ, міст; органи самоорганізації населення. У містах з районним поділом за рішенням територіальної громади міста або міської ради відповідно до цього Закону можуть утворюватися районні в місті ради. Районні в містах ради утворюють свої виконавчі органи та обирають голову ради, який одночасно є і головою її виконавчого комітету.

Складові системи місцевого самоврядування, зокрема, як суб'єкти контрольної діяльності, отримують самостійний статус в законах «Про органи самоорганізації населення», «Про статус депутатів місцевих рад», «Про добровільне об'єднання територіальних громад» тощо.

Висновки. Дослідження свідчить про розгалужену та складну конструкцію, архітектоніку суб'єктів контрольної діяльності у місцевій публічній владі, місцевому врядуванні України.

Їх склад визначається багатьма конституційно-правовими актами і галузевим законодавством, не узгодженим з огляду на спрямованість контрольної діяльності.

Це свідчить про необхідність розробки та впровадження концептуальних засад законодавчого забезпечення контролю, контрольної діяльності у місцевій публічній владі.

\section{Список використаних джерел}

1. Батанов О. В. Муніципальна влада в Україні: проблеми теорії та практики : моногр. / Відп. ред. М. О. Баймуратов. - К. : Видавництво «Юридична думка», 2010. -656 с.

2. Крусян А. Р. Сучасний український конституціоналізм : моногр. / А. Р.Крусян. - К. : Юрінком Інтер, 2010. 560 c. [Електронний ресурс]. - Режим доступу : http://dspace.onua.edu.ua/handle/11300/965

3. Калиновський Б. В. Місцева публічна влада в Україні: конституційно-правові засади функціонування та розвитку : дис.. ... докт. юрид. наук. - К., 2017. - [Електронний ресурс]. - Режим доступу : http://elar.naiau.kiev. ua//pdf

4. Сушинський O. I. Теоретико-методологічні засади контролю у сфері публічної влади : автореф. дис. ... д-ра наук з держ. упр. : Укр. Акад. держ. упр. при Президентові України. - К., 2003. - 36 с. [Електронний ресурс]. Режим доступу : http://irbis-nbuv.gov.ua/cgi-bin/irbis64r_81/cgiirbis_64.exe

5. Смоляр О. А. Державний та громадський контроль у сфері місцевого самоврядування : дис. … канд. юрид. наук. - Харків, 2016 [Електронний ресурс]. - Режим доступу : http://nauka.nlu.edu.ua/download/diss/Smolyar/d_ Smolyar.pdf

6. Вітвіцький С. С. Контроль як гарантія законності діяльності публічної адміністрації : дис. ... докт. юрид. наук. - Харків, 2016. - 480 c. [Електронний ресурс]. - Режим доступу : http://ekhnuir.univer.kharkov.ua/pdf

7. Карабін Т. О. Розподіл повноважень публічної адміністрації (доктринальний адміністративно-правовий аналіз : автореф. дис. ... докт. юрид. наук: Запорізький національний університет. - Запоріжжя, 2016 [Електронний ресурс]. - Режим доступу : http://phd.znu.edu.ua/page//aref/07_2016/Karabin_pdf

8. Буханевич А. Публічна адміністрація як інститут оптимізації публічного контролю в громадянському суспільстві. - [Електронний ресурс]. - Режим доступу : http://visnyk.academy.gov.ua/wp-content/ uploads/2013/11/2010-2-8.pdf

9. Косінов С. А. Контроль над публічною владою: теоретико-правова характеристика // Вісник Національної академії правових наук України. - № 4 (75). - 2013. - С. $49-57$ [Електронний ресурс]. - Режим доступу : www. irbis-nbuv.gov.ua/cgi-bin/irbis.../cgiirbis_64.exe?

10. Вітвіцький С. С. Контроль як гарантія законності діяльності публічної адміністрації : дис. ... докт. юрид. наук. - Харків, 2016. - 480 с. [Електронний ресурс]. - Режим доступу : http://ekhnuir.univer.kharkov.ua/pdf

11. Постанова Кабінету Міністрів України «Про затвердження Порядку сприяння проведенню громадської експертизи діяльності органів виконавчої влади від 5 листопада 2008 року № 976 [Електронний ресурс]. - Режим доступу : http://zakon.rada.gov.ua/laws/show/976-2008-\%D0\%BF/print

12. Конституиія України // Відомості Верховної ради України (ВВР), 1996, № 30, ст. 141.

13. Закон України «Про Кабінет Міністрів України» від 27 лютого 2014 року № 794-VII. // Відомості Верховної Ради (ВВР), 2014, № 13, ст. 222; Закон України «Про центральні органи виконавчої влади» від 17 березня 2011 р. № 3166-VI // Відомості Верховної Ради України (ВВР), 2011, № 38, ст. 385; Закон України «Про місцеві державні адміністрації» від 9 квітня 1999 р., №586-ХІУ // Відомості Верховної Ради України (ВВР), 1999, №№ 20-21, ст.190; Закон України «Про військово-цивільні адміністрації» від 3 лютого 2015 року № 141-VIII // Відомості Верховної Ради України (ВВР), 2015, № 13, ст. 87; Закон України «Про місцеве самоврядування в Україні» 
від 21 травня 1997 р., № 280/97-ВР // Відомості Верховної Ради України (ВВР), 1997, № 24, ст. 170; Закон України «Про органи самоорганізації населення» від 11 липня 2001 р., № 2625-III // Відомості Верховної Ради України (ВВР), 2001, № 48, ст. 254; Закон України «Про статус депутатів місцевих рад» від 11 липня 2002 року № 93-IV // Відомості Верховної Ради України (ВВР), 2002, № 40, ст. 290; Указ Президента України «Про оптимізацію системи центральних органів виконавчої влади» від 9 грудня 2010 р. №1085/2010 [Електронний ресурс]. - Режим доступу : https://www.president.gov.ua/documents/10852010-121; Постанова Кабінету Міністрів України «Про оптимізацію системи центральних органів виконавчої влади» від 10 вересня 2014 року № 442 // Офіційний вісник України від 23.09.2014 — 2014, № 74, стор. 57, стаття 2105, код акта 73930/2014.

14. Закон України «Про основні засади державного нагляду (контролю) у сфері господарської діяльності» від 5 квітня 2007 року № 877-V // Відомості Верховної Ради України (ВВР), 2007, № 29, ст. 389.

15. Пивоваров К. В. Удосконалення системи контролю в державному управлінні України : дис. ... докт. наук 3 держ. управління. - К., 2017 [Електронний ресурс]. - Режим доступу : http://nuczu.edu.ua/img/articles/1599/dis...pdf

16. Указ Президента України «Про оптимізацію системи центральних органів виконавчої влади» від 9 грудня 2010 p. №1085/2010 [Електронний ресурс]. - Режим доступу : http://zakon.rada.gov.ua/laws/show/1085/2010/print

17. Постанова Кабінету Міністрів України «Про оптимізацію системи центральних органів виконавчої влади» від 10 вересня 2014 року № 442 // Офіційний вісник України від 23.09.2014. - 2014. - № 74, стор. 57, стаття 2105 , код акта 73930/2014.

\section{References}

1. Batanov O. V. Municipal'na vlada v Ukraïni: problemi teoriï ta praktiki: Monografiya/Vidp. red.. M. O. Bajmuratov. K. : Vidavnictvo «Yuridichna dumka», 2010. - $656 \mathrm{~s}$.

2. Krusyan A. R. Suchasnij ukraïns'kij konstitucionalizm: monogra $\neg$ fiya / A.R.Krusyan. - K. : Yurinkom Inter, 2010. 560 s. - [Elektronnij resurs]. - Rezhim dostupu : http://dspace.onua.edu.ua/handle/11300/965

3. Kalinovs'kij B.V. Misceva publichna vlada v Ukraïni: konstitucijno-pravovi zasadi funkcionuvannya ta rozvitku. Disertaciya... dokt. yurid. nauk. - Kiïv, 2017. - [Elektronnij resurs]. - Rezhim dostupu: http://elar.naiau.kiev.ua//pdf

4. Sushins 'kij O. I. Teoretiko-metodologichni zasadi kontrolyu u sferi publichnoï vladi: avtoreferat disertaciï... d-ra nauk z derzh. upr.: Ukr. Akad. derzh. upr. pri Prezidentovi Ukraïni. - K., 2003. - 36 s. - [Elektronnij resurs]. - Rezhim dostupu : http://irbis-nbuv.gov.ua/cgi-bin/irbis64r_81/cgiirbis_64.exe

5. Smolyar O. A. Derzhavnij ta gromads'kij kontrol' u sferi miscevogo samovryaduvannya. Disertaciya na zdobuttya naukovogo stupenya kandidata yuridichnih nauk. - Harkiv, 2016. - [Elektronnij resurs]. - Rezhim dostupu : http:// nauka.nlu.edu.ua/download/diss/Smolyar/d_Smolyar.pdf

6. Vitvic'kij S. S. Kontrol' yak garantiya zakonnosti diyal'nosti publichnoï administraciï. - Disertaciya... dokt. yurid. nauk. - Harkiv, 2016. - 480 s. [Elektronnij resurs]. - Rezhim dostupu : http://ekhnuir.univer.kharkov.ua/pdf

7. Karabin T. O. Rozpodil povnovazhen' publichnoï administraciï (doktrinal'nij administrativno-pravovij analiz. Avtoreferat disertaciï ... dokt. yurid. nauk: Zaporiz'kij nacional'nij universitet. - Zaporizhzhya, 2016 [Elektronnij resurs]. - Rezhim dostupu : http://phd.znu.edu.ua/page//aref/07_2016/Karabin_pdf

8. Buhanevich A. Publichna administraciya yak institut optimizaciï publichnogo kontrolyu vgromadyans'komu suspil'stvi [Elektronnij resurs]. - Rezhim dostupu : http://visnyk.academy.gov.ua/wp-content/uploads/2013/11/2010-2-8.pdf

9. Kosinov S. A. Kontrol' nad publichnoyu vladoyu: teoretiko-pravova harakteristika // Visnik Nacional'noï akademiï pravovih nauk Ukraïni. - № 4 (75), 2013. - S. 49-57 [Elektronnij resurs]. - Rezhim dostupu: www.irbis-nbuv.gov.ua/ cgi-bin/irbis.../cgiirbis_64.exe?

10. Vitvic'kij S. S. Kontrol' yak garantiya zakonnosti diyal'nosti publichnoï administraciï. - Disertaciya... dokt. yurid. nauk. - Harkiv, 2016. - 480 s. [Elektronnij resurs]. - Rezhim dostupu : http://ekhnuir.univer.kharkov.ua/pdf

11. Postanova Kabinetu Ministriv Ukraïni «Pro zatverdzhennya Poryadku spriyannya provedennyu gromads'koï ekspertizi diyal’nosti organiv vikonavchoï vladi vid 5 listopada 2008 roku № 976 [Elektronnij resurs]. - Rezhim dostupu : http://zakon.rada.gov.ua/laws/show/976-2008-\%D0\%BF/print

12. Konstituciya Ukraïni // Vidomosti Verhovnoï radi Ukraïni (VVR), 1996, № 30, st. 141.

13. Zakon Ukraïni «Pro Kabinet Ministriv Ukraïni» vid 27 lyutogo 2014 roku № 794-VII // Vidomosti Verhovnoï Radi (VVR), 2014, № 13, st.222; Zakon Ukraïni «Pro central'ni organi vikonavchoï vladi» vid 17 bereznya 2011 r. № 3166-VI // Vidomosti Verhovnoï Radi Ukraïni (VVR), 2011, № 38, st. 385; Zakon Ukraïni «Pro miscevi derzhavni administraciï» vid 9 kvitnya 1999 r., №586-HIU // Vidomosti Verhovnoï Radi Ukraïni (VVR), 1999, №№ 20-21, st.190; Zakon Ukraïni «Pro vijs'kovo-civil'ni administraciï» vid 3 lyutogo 2015 roku № 141-VIII // Vidomosti Verhovnoï Radi (VVR), 2015, № 13, st. 87; Zakon Ukraïni «Pro misceve samovryaduvannya v Ukraïni» vid 21 travnya 1997 r., № 280/97-VR // Vidomosti Verhovnoï Radi Ukraïni (VVR), 1997, № 24, st. 170; Zakon Ukraïni «Pro organi samoorganizaciï naselennya» vid 11 lipnya 2001 r., № 2625-III // Vidomosti Verhovnoï Radi Ukraïni (VVR), 2001, № 48, st. 254; Zakon Ukraïni «Pro status deputativ miscevih rad» vid 11 lipnya 2002 roku № 93-IV // Vidomosti Verhovnoï Radi Ukraïni (VVR), 2002, № 40, st. 290; Ukaz Prezidenta Ukraïni «Pro optimizaciyu sistemi central'nih organiv vikonavchoï vladi» vid 9 grudnya 2010 r. №1085/2010 [Elektronnij resurs]. - Rezhim dostupu : 
https://www.president.gov.ua/documents/10852010-121; Postanova Kabinetu Ministriv Ukraïni «Pro optimizaciyu sistemi central'nih organiv vikonavchoï vladi» vid 10 veresnya 2014 roku № 442 // Oficijnij visnik Ukraïni vid 23.09.2014. - 2014 r., № 74, stor. 57, stattya 2105, kod akta 73930/2014.

14. Zakon Ukraïni «Pro osnovni zasadi derzhavnogo naglyadu (kontrolyu) u sferi gospodars'koï diyal'nosti» vid 5 kvitnya 2007 roku № 877-V // Vidomosti Verhovnoï Radi Ukraïni (VVR), 2007, № 29, st. 389.

15. Pivovarov $K$. $V$. Udoskonalennya sistemi kontrolyu v derzhavnomu upravlinni Ukraïni. - Disertaciya... dokt. nauk $\mathrm{z}$ derzh. upravlinnya. - K., 2017 [Elektronnij resurs]. - Rezhim dostupu : http://nuczu.edu.ua/img/articles/1599/dis...pdf

16. Ukaz Prezidenta Ukraïni «Pro optimizaciyu sistemi central'nih organiv vikonavchoï vladi» vid 9 grudnya $2010 \mathrm{r}$. №1085/2010 [Elektronnij resurs]. - Rezhim dostupu : http://zakon.rada.gov.ua/laws/show/1085/2010/print

17. Postanova Kabinetu Ministriv Ukraïni «Pro optimizaciyu sistemi central'nih organiv vikonavchoï vladi» vid 10 veresnya 2014 roku № 442 // Oficijnij visnik Ukraïni vid 23.09.2014 - 2014 r., № 74, stor. 57, stattya 2105, kod akta $73930 / 2014$.

\section{Пухтинський М. О. Суб’скти контрольної діяльності у місцевій публічній владі}

У статті розглядаються конституційно-правового аспекти визначення складу суб'єктів контролю та контрольної діяльності у місцевій публічній владі, місцевому врядуванні України. Досліджуються теоретичні положення щодо публічної, муніципальної влади, публічної адміністрації, які знайшли відображення в юридичній літературі.

Представлені міркування дають змогу зробити деякі попередні висновки щодо аксіології контролю, контрольної діяльності у місцевій публічній владі з огляду на вимір місцевого врядування. Більшість дослідників розглядають контроль та контрольну діяльність з позиції широкої концепції його соціальної природи і призначення. В той же час, категорії «публічна влада», «публічна адміністрація» обмежують склад суб'єктів контрольної діяльності та контролю державно-владними і муніципально-владними інститутами. Переважно йдеться про місцеві органи виконавчої влади та органи місцевого самоврядування. Деякі автори навіть вважають, що до суб'єктів державного, адміністративного контролю можна віднести лише тих, хто безпосередньо виконують виконавчо-розпорядчі функції і повноваження.

Вбачається, що контроль, контрольна діяльність, суб'єкти контролю у місцевій публічній владі 3 точки зору виміру місцевого врядування дозволяє окреслити склад цих суб'єктів.

Акцентується на тому, що до цього часу не існує цілісного механізму соціального, державного, адміністративного, громадського контролю в його статутному та процедурному розумінні.

Висловлюються пропозиції щодо вдосконалення правового і концептуального визначення складу суб'єктів контролю та контрольної діяльності у місцевій публічній владі, місцевому врядуванні України.

Ключові слова: публічна, муніципальна влада, місцеве врядування, місцеве самоврядування, публічне управління, місцеві органи виконавчої влади, органи місцевого самоврядування, контроль, контрольна діяльність.

\section{Puhtinsky M. O. Subjects of control activity in local public authorities}

The article deals with the constitutional and legal aspects of determining the composition of subjects of control and control activities in local public authorities, local governance of Ukraine. The theoretical positions concerning public, municipal authorities, public administration, which are reflected in the legal literature, are researched.

The arguments presented give some preliminary conclusions about the axiology of control, control activities in local public authorities, taking into account the measurement of local governance. Most researchers consider control and control activities from the standpoint of a broad concept of its social nature and purpose. At the same time, the categories «public authority», "public administration» limit the composition of subjects of control and control of state-owned and municipal authorities. Mostly it is about local executive bodies and bodies of local self-government. Some authors even believe that the subjects of state, administrative control can be attributed only to those who directly execute executive and regulatory functions and powers.

It is seen that control, control activities, and subjects of control in local public authorities in terms of measuring local governance can determine the composition of these entities.

It is accentuated that to this time there is no integral mechanism of social, state, administrative, public control in its statutory and procedural sense.

The research shows the ramified and complex design, the architectonics of the subjects of control activity in the local public authorities, local government of Ukraine. Their composition is determined by many constitutional and legal acts and sectoral legislation, not coordinated in view of the direction of control activities.

This testifies to the need to develop and implement the conceptual framework for legislative control of control and control activities in local public authorities.

Proposals on improving the legal and conceptual definition of the subjects of control and control activities in local public authorities, local governance of Ukraine are expressed.

Key words: public, municipal authorities, local governance, local self-government, public administration, local executive bodies, local self-government bodies, control, control activities.

DOI: 10.33.66.3/2524-017X-2019-10-329-336 